\title{
Seagrass Mapping Based on Satellite Image Worldview-2 by Using Depth Invariant Index Method
}

\author{
Agnestesya Manuputty*, Jonson Lumban Gaol and Syamsul Bahri Agus \\ Department of Marine Science and Technology Faculty of Fisheries and Marine Sciences \\ Bogor Agricultural University \\ Jl. Agatis, Kampus IPB Dramaga Bogor 16680 Indonesia \\ Email: chaa_nez@yahoo.com
}

\begin{abstract}
Seagrass has an important role in coastal areas, so it's sustainability need to be maintained. One effort to preserve it is sustainable manner management of segrass based on the spatial data using remote sensing techniques. The aim of this study was to map seagrass ecosystems and to determining the accuracy level from classification results that obtained by the WorldView-2 images. This study was conducted in Karang Bongkok and Kotok Islands in August 2014 and March 2015. The satellite images data used on this study was WorldView-2 satellite images at the acquisition date of October 5, 2013. The method used to conduct image processing data is Depth Invariant Index (DII) using Support Vector Machine (SVM) classification. The result shows that seagrass mapping in Karang Bongkok and Kotok Islands using DII transformation has 19.5112 ha areas with 72\% accuracy on Karang Bongkok Island and 2.5704 ha areas with of $83 \%$ accuracy on Kotok Island.
\end{abstract}

Key words: Seagrass mapping, DII, SVM, Karang Bongkok, Kotok Island.

\section{Introduction}

Seagrass has important role, both in economic and ecological resource values. One role of seagrass economically can produce the value world's ecosystem service about US\$19,000 per ha/yr (Costanza et al., 1997).

The ecological role of seagrass is help to reduce the pounding waves, as the refuge area, spawning and feeding grounds for the marine biota (Bortone 2000). Beside the role of economic and ecologic resource values, seagrass is also as carbon sequestration media. Agustin et al. (2014) suggested that seagrass can absorb carbon from atmosphere in the western seasons about 0.502 and $5.971 \mathrm{mmolC}^{-2}$ a day. There is estimated that carbon sequestration will be directly proportional to the seagrass areas, where the greater seagrass areas so the carbon sequestration is higher and conversely (Duarte and Gattuso, 2008 in Setiawan 2012). Based on the important role of seagrass in coastal areas, so the preservation of seagrass needs management and preserve for the sustainability and optimality used. One effort to preserve it is sustainable manner management of segrass based on the spatial data using remote sensing techniques.

The use of remote sensing technology for the mapping of seagrass has many advantages compared with conventional manner (Green et al., 2000). Seagrass mapping using a variety of satellite sensors have been done, to determine the ability of a satellite sensor to produce a more accurate map. Besides the ability of satellite images to map seabed habitats, especially for the seagrass ecosystem, there is a tough challenge due to the small area of seagrass ecosystem. So that the better algorithm to process the satellite images for produce the more accurate map is needed.

Image processing using depth invariant index (DII), is a method developed by Lyzenga (1981) to correction the water column by the ratio of different bands, with the assumption that the value of this ratio will be same in many substrate (Budiman et al., 2013). Basically, the process of calculating the value of the ratio band DII resulting from sampling on the same substrate having different depths. Correction of the water column conducted to reduce or eliminate the influence of water column in the bottom to mapping object based on approach to satellite images.

Many research about seagrass mapping using various satellite sensors with DII method has been done and produce the different level on accuracy. Amran (2010), has investigated the Quickbird satellite capabilities for mapping seagrass cover on Barranglompo and Barrangcaddi Islands, in 
Makassar, used DII image enhancement with 75\% accuracy. In addition, mapping studies of seagrass ecosystems in the Philippines by WorldView-2 satellite images, using DII with Maximum likelihood classification has $75.54 \%$ accuracy (Tamondong et al., 2013).

The seagrass mapping research using DII method with algorithm of Support Vector Machine (SVM) classification is still rarely to be done. Information on seagrass classifications with using SVM algorithm is still limited. The SVM algorithm in classification is often used for coral reefs, mangroves mapping and bioinformatics. Therefore, this study aims to map the seagrass ecosystems with DII methods and find how much accuracy of classification using WorldView-2 images in the Karang Bongkok and Kotok Islands.

\section{Materials and Methods}

This research was conducted in Karang Bongkok and Kotok Islands in the National Park of Thousand Islands (Figure 1), in August 2014 and March 2015. The Karang Bongkok and Kotok are the archipelagic islands that has coastal ecosystem. There are the seagrass ecosystem with still in better condition.

The tools used in this study consist of Global Positioning System (GPS) for in situ measurement, transect quadrant, meter, stationery, The guidelines for seagrass identification (Seagrass Watch), underwater camera, snorkel and mask. The processing data tools are used software for processing image data and laptop. The materials used in this study is the satellite WorldView- 2 data that has resolution spatial of $1.8 \mathrm{~m}$ and date acquisition is October 5, 2013.

Data seagrass ecosystems retrieval based on compatibility between image resolution and accuracy of GPS. Seagrass component data retrieval was conducted by applying the quadrant transects technique (Roelfsema et al., 2008; English et al., 1997). The length of observation transect is $30 \mathrm{~m}$ that perpendicular and parallel to the coast which the observation in every stations were conducted by 3 times in different locations.

Quadrant size to collect seagrass is $1 \times 1 \mathrm{~m}$ and divided into 4 segments which $25 \mathrm{~cm}$ size each segments placed along the transect line. Observation of the data was conducted using Seagrass Watch methods (McKenzie et al., 2003).

\section{Image processing data}

Image processing data WorldView-2 performed with several stages such as geometric correction, radiometric conversion and atmospheric correction, image segmentation and image enhancement. Geometric correction is a process of adjusting position of the satellite image according to the Earth's surface position. Geometric correction on the WorldView-2 was conducted by using the model of rational polynomial coefficient (RPC). Mathematical model RPC is using to define the connection of coordinate each object and space $(\phi$, $\lambda, h)$, where $\phi$ is the geographic latitude, $\lambda$ is the geographical longitude and $h$ is the height above the ellipsoid to the coordinates of the image (Line, Sample) (Grodecki and Dial, 2003).

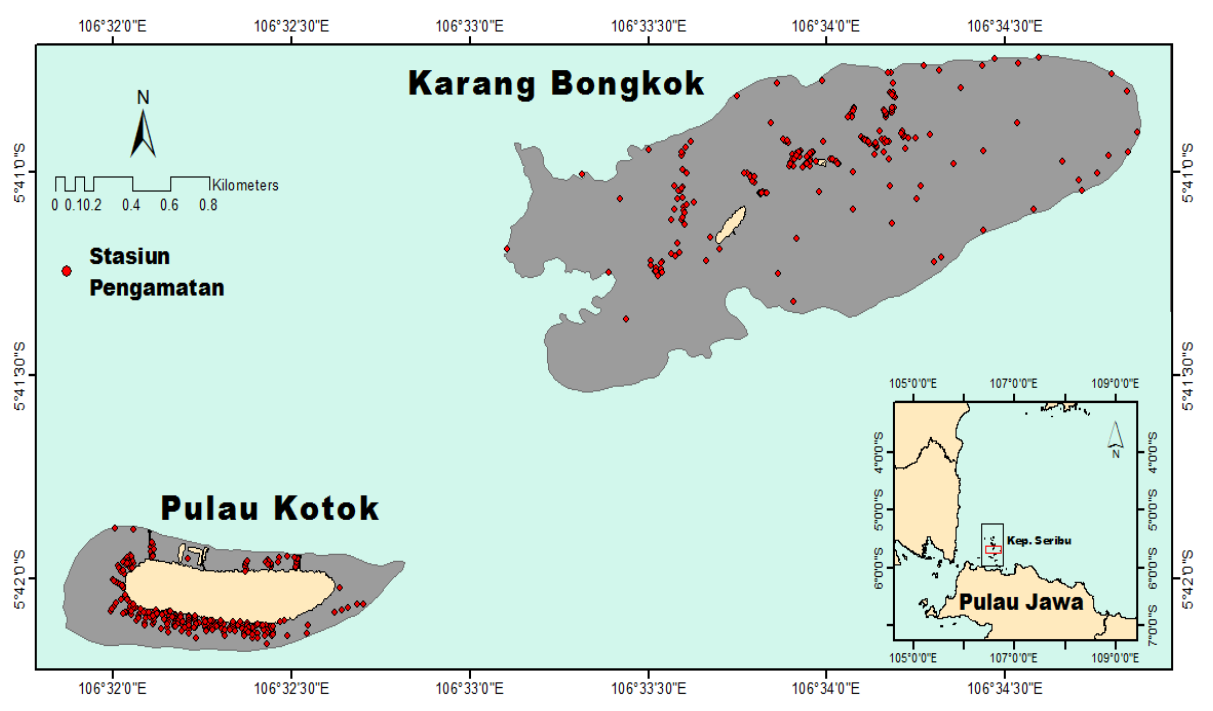

Figure 1. Research Location. 
Atmospheric correction was conducted to reduce the atmosphere effects to get the surface spectral reflectance from an image. Atmospheric correction is using ATCOR_2 module (Atmospheric Correction) that utilized MODTRAN 4+ radiation transfer code (Richter, 2004).

Radiometric correction is a repair technique of satellite images to remove atmospheric effect. There is due to effects correction that caused appearance of the earth become no sharp. This correction includes of effects correction that associated with the sensors to enhance contrast of each image pixel. So that the recorded object is easily to interpreted or analyzed to generate data or information that according to the ground turth. (Supriatna and Sukartono 2002). Radiometric correction can be conducted in several stages, the conversion digital number (DN) to satellite radians and radians to reflectance.

Image enhancement used to improve the gray level from an image. Image enhancement process in this study conducted by correction of the water column with using the DII. DII equation is as follows (Lyzenga, 1981):

$$
\begin{gathered}
\text { depth-invariant index } x_{i j}=\ln \left(\mathrm{L}_{i}\right)-\left\lfloor\left(\frac{K_{i}}{K_{j}}\right) \ln \left(\mathrm{L}_{j}\right)\right\rfloor \\
\mathrm{K}_{\mathrm{i}} / \mathrm{K}_{\mathrm{j}}=\mathrm{a}+\sqrt{\left(\mathrm{a}^{2}+1\right)} \text { dan } \mathrm{a}=\frac{\sigma_{i i}-\sigma_{i j}}{2 \sigma_{i j}}
\end{gathered}
$$

Where, $\mathrm{Li}$ and $\mathrm{Lj}=$ reflectance value of the band-I and band-j, $\mathrm{Ki} / \mathrm{Kj}=$ ratio coeffisient attenuation of the band-i and j, oii = Variance of the band $\mathrm{i}, \sigma \mathrm{jj}=$ Variance of the band $\mathrm{j}$ and $\sigma \mathrm{ij} \mathrm{ij}=$ Covariance of the band.

Image classification is using SVM algorithm. SVM is a classification techniques to find a vector or line that has functions as the separator of two classes by maximizing the boundaries between the classes. Vapnik and Kotz (1982) explains that the simple concept of SVM is the classification of image pixels by finding the best hyperplane. SVM has functions as a separator of two classes in the space based on the statistical distribution patterns in the region feature class as an input in the classification process. SVM parameter optimization in this study is using a radial basis function (RBF) kernel, to determine the ability of the SVM algorithm for generate the seagrass mapping accuracy. SVM with RBF kernel equation is as follows (Vapnik, 1995):

$$
K\left(x_{i}, x_{j}\right)=\exp \left(-v|| x_{i}-x_{j}||^{2}\right) y>0
$$

Where, $\gamma$ is a kernel parameter. $\gamma$ value on the type of RBF kernel is 0 or 1 , if the value of $\gamma=0$ then the learning process speed is 1 per dimension features.

The last classification process is accuracy test, where the classification results will be validate with observation data using conversion matrix to show the level accuracy. The accuracy calculation can be conducted by User Accuracy (UA), Producer Accuracy (PA) and Overall Accuracy (OA) calculation (Congalton and Green, 2009).

\section{Results and Discussion}

\section{Water column correction}

Correction calculations in the water column influenced by the range of the band. This band's range will affect the deep of band that using to detect the water substrate. WorldView-2 has 8 bands that consist of 6 bands for visible light and 2 bands as infrared band. The band was used to correction the water column consists of 6 visible bands with wave length about 400-745 nm and produce 15 pair band to get the $\mathrm{ki} / \mathrm{kj}$. The correlation result based on the calculation of $\mathrm{kj} / \mathrm{ki}$ has the capability to obtained the pair band that can reflect the sand value.

There are 3 pair bands that have higher correlation that are costal-blue, yellow-red and redrededge pair band (Table 1 ) that presented on b-plot graphs of logarithm transform for homogeneous base substrate with different depth (Figure 2). The pixel value is not fully given the clear image of basesubstrate type which influenced by some factors such as natural variation of base reflectance, water quality and sensors's characteristic. In this study, the substrate that used to perform the water column correction process was sand, because sand has the higher reflectance compared with the other substrates.

The result showed $\mathrm{ki} / \mathrm{kj}$ about $0.89-3.21$ is the range of $\mathrm{ki} / \mathrm{kj}$ on the marine waters (Lyzenga, 1981). The greater value $\mathrm{ki} / \mathrm{kj}$ shows that the identification decreased of the bottom substrate of waters. Variation attenuation coefficient spectral bands depending on the specific type of waters to determination of the image sample. The calculation of $\mathrm{ki} / \mathrm{kj}$ value in this study indicate that pair band Coastal and blue (1/2) has wavelength range is larger and value of $\mathrm{ki} / \mathrm{kj}$ has smaller than other pair bands. That is because that coastal-blue wavelengths more reflected in the waters of the absorbed, so the object is located on the substrate can be detected. The greater ranges of the wavelength pairs band than the value of the $\mathrm{ki} / \mathrm{kj}$ 

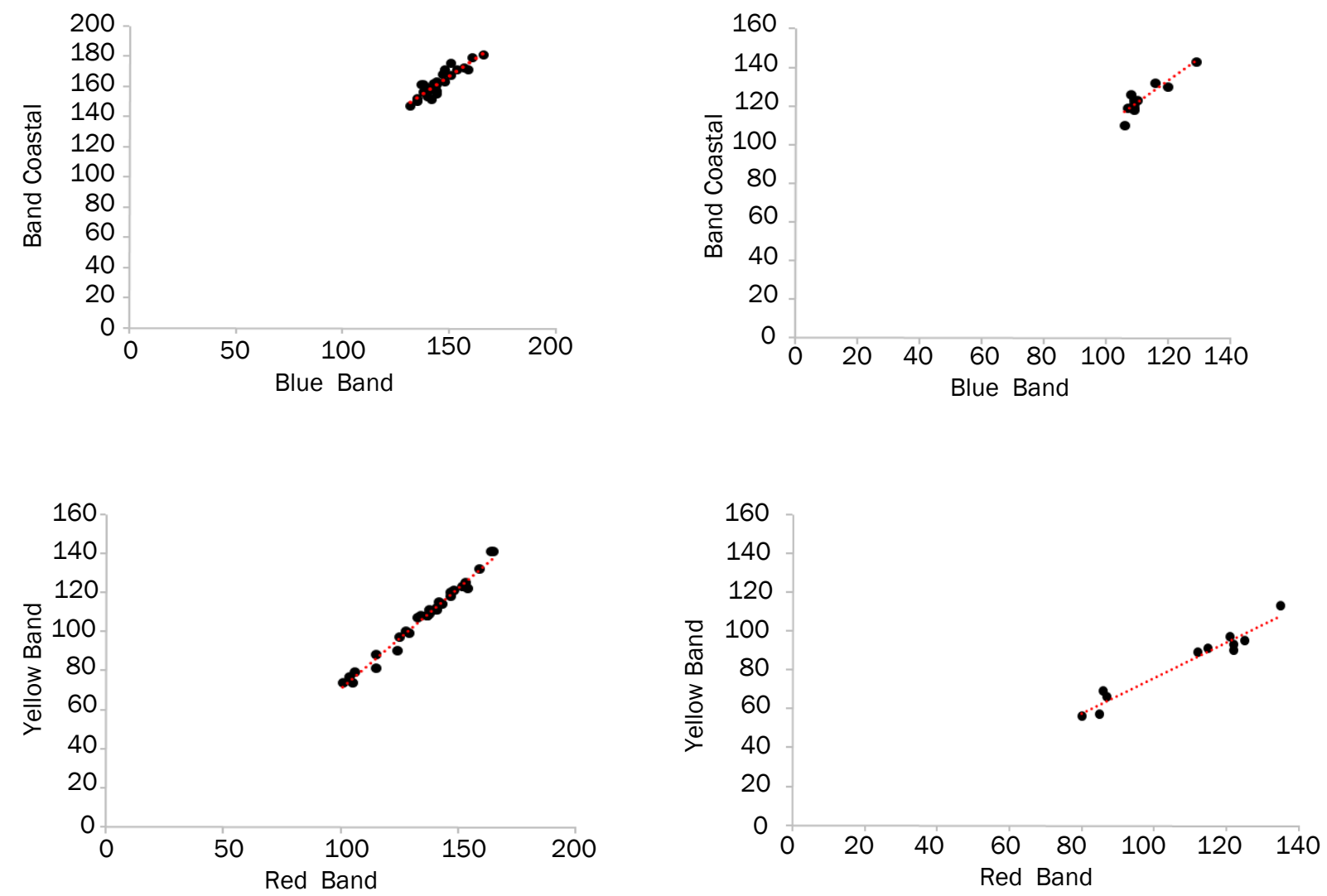

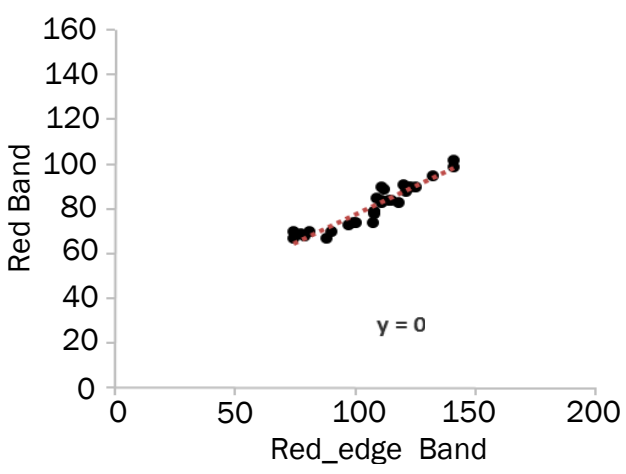

(a)

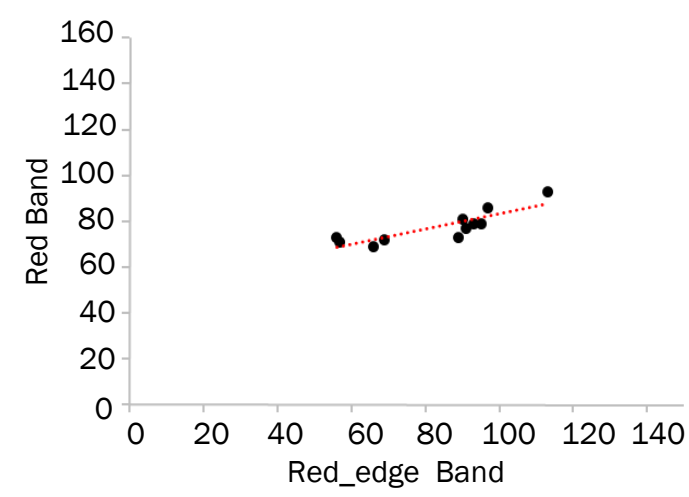

(b)

Figure 2. Biplot logarithmic transformation bands on the WorldView-2 in Karang Bongkok (a) and Kotok Island (b).

ratio getting smaller, which means that the ability to identify bottom sea types getting better (Wahiddin, 2015). Green et al., 2000 recommends if the satellite images has multiple bands with the good penetration properties into the water therefore, the whole DII band should be used for the classification process. The results of $\mathrm{ki} / \mathrm{kj}$ value was obtained, then the correction of the water column was conducted to determine the effect of sampling on waters column with the same type of substrate. Water column correction aims to get a new images by merge two bands on visible band, which can penetrate into the column waters to the certain depth, so it can be used to identify the bottom object. 
Table 1. Kj/Ki and pair band correlation.

\begin{tabular}{ccc}
\hline \multirow{2}{*}{ Pair band } & \multicolumn{2}{c}{$\mathrm{Ki} / \mathrm{Kj}$} \\
\cline { 2 - 3 } & $\begin{array}{c}\text { Karang Bongkok } \\
\text { Island }\end{array}$ & $\begin{array}{c}\text { Kotok } \\
\text { Island }\end{array}$ \\
\hline $\begin{array}{c}\text { Coastal-Blue (1/2) } \\
\text { Yellow-Red (4/5) } \\
\text { Red-RedEdge } \\
(5 / 6)\end{array}$ & 0.89 & 0.59 \\
\hline
\end{tabular}

\section{Seagrass classification}

Seagrass habitat classification that using SVM algorithm with RBF kernel in Karang Bongkok and Kotok Island was presented in Figure 3 . Seagrass classification habitat on DII image transformation was able to identify the class of seagrass substrate such as rubble, coral, lagoon, sand, sand mixed seagrass and sand mixed rubble with the varying of mapping result.

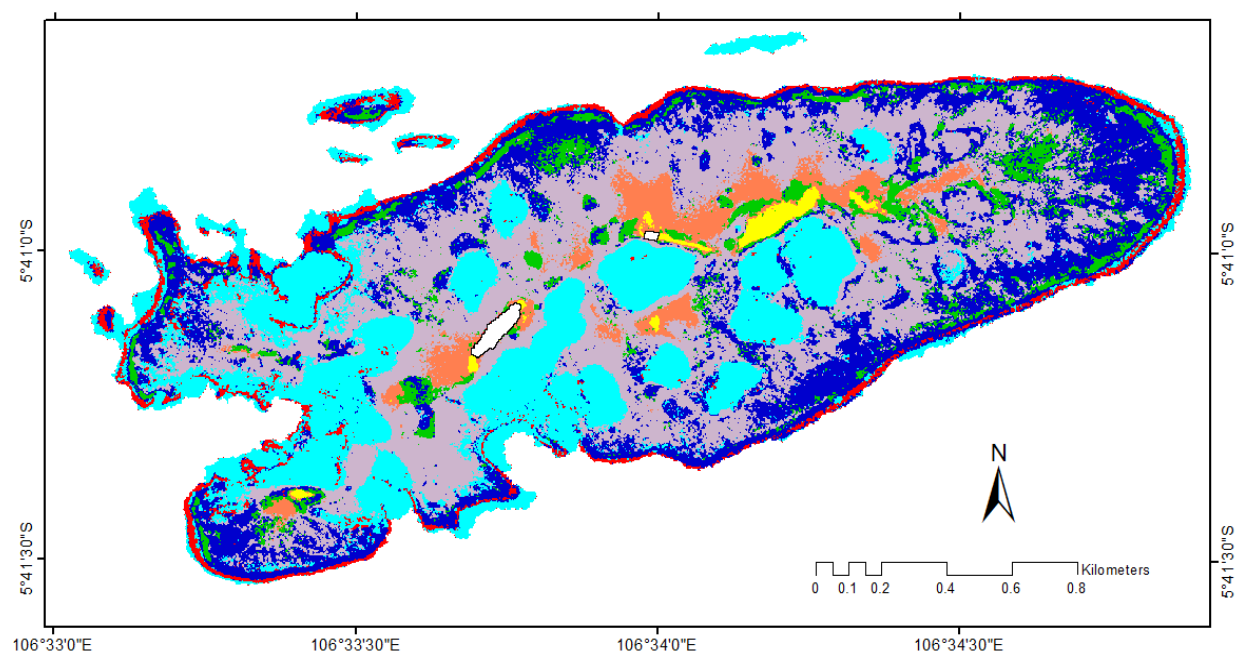

(a)

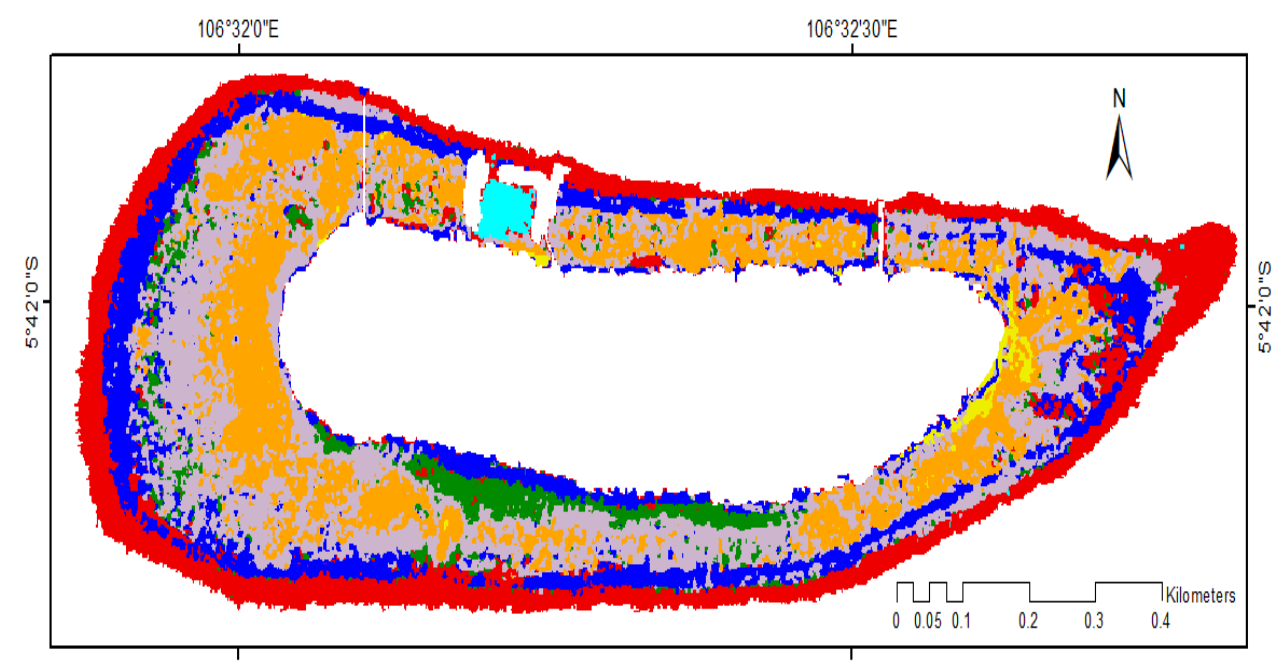

(b)

Figure 3. Map of thematic seagrass with some class of benthic composite, from the results of the classification SVM algorithm on the DII image transformation of Karang Bongkok (a) and Kotok Island (b).

Note. $\square=$ seagrass, $\square=$ sands, $\square=$ rubble, $\square=$ coral, $\square=$ lagoon, $\square=$ Seagrass and Sands,

= Sands and Rubble 


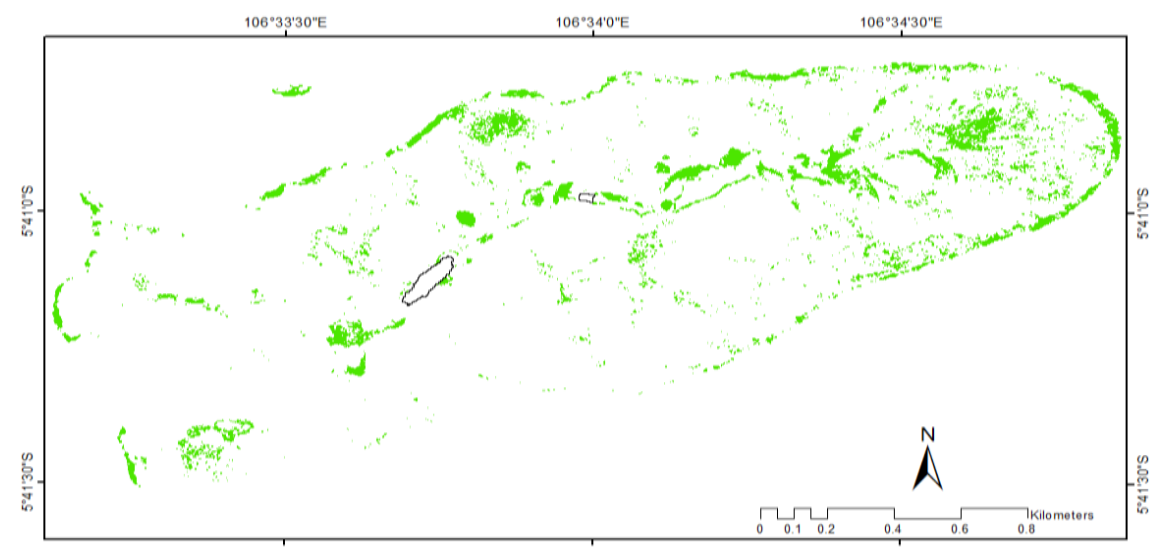

(a)

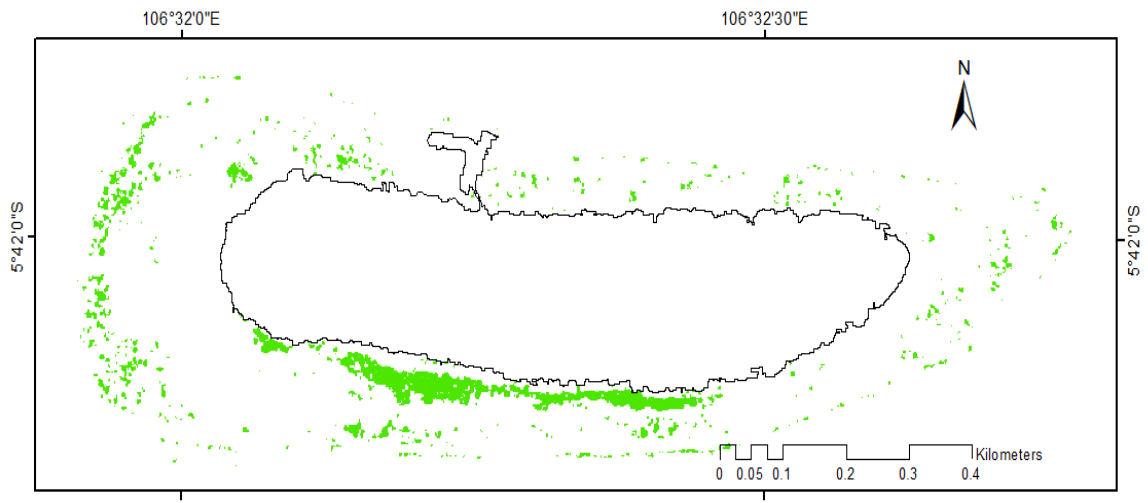

(b)

Figure 4. Map of the classification results of seagrass with using SVM algorithm on DII image transformation of in Karang Bongkok (a) and Kotok Island (b).

Note. $\sim$ = Coastline, $\square=$ Seagrass, $\square$ = Non Seagrass

Table 2. Results of seagrass mapping accuracy on several classes of benthic habitat composite

\begin{tabular}{llll}
\hline \multicolumn{1}{c}{ Location } & PA & UA & OA \\
\hline Karang Bongkok Island & & & \\
Coral reef & $17 \%$ & $100 \%$ & \\
Lagoon & $100 \%$ & $63 \%$ & \\
Segrass & $73 \%$ & $96 \%$ & $72.38 \%$ \\
Sand & $80 \%$ & $100 \%$ & \\
Sand mix Seagrass & $100 \%$ & $100 \%$ & \\
Sand mix Rubble & $100 \%$ & $50 \%$ & \\
Rubble & $57 \%$ & $35 \%$ & \\
Kotok Island & & & \\
Coral reef & $87 \%$ & $81 \%$ & \\
Lagoon & $100 \%$ & $100 \%$ & \\
Segrass & $72 \%$ & $100 \%$ & \\
Sand & $100 \%$ & $10 \%$ & \\
Sand mix Seagrass & $95 \%$ & $100 \%$ & \\
Sand mix Rubble & $100 \%$ & $50 \%$ & \\
Rubble & $100 \%$ & $64 \%$ & \\
\hline
\end{tabular}


Seagrass classification by SVM algorithm with RBF kernel type in the DIl image transformation produce an area of 19.5112 ha (Karang Bongkok) and 2.5704 ha (Kotok Island) (Figure 4).

Candace and Dixon (2004) apply the statistical calculations SVM and analysis neural network (ANN) on classification of land cover with using Landsat 5 TM in DeSoto Country Florida with 7 classes of covery showed that, SVM has good ability on the number of training small samples compared to ANN. Theret is because SVM algorithm can directly interpret the colors of pixels as a vector which has a good classification capability (Mehta et al., 2007; Wahiddin 2015). Classification results with using SVM algorithm in remote sensing, has a good ability to classify data by a small amount and yield good accuracy compared to classification by traditional techniques (Mountrakis et al., 2011).

Overall the classification results with images WorldView 2 in this study has a good accuracy. Based on the data survey that has collected, it can be determined the overall accuracy (OA), producer accuracy (PA) and user accuracy (UA). The accuracy of the classification results are presented in Table 2.

\section{Conclusion}

This study results concluded that, the seagrass in Karang Bongkok Island and Kotok Island can be detected well and have the high level of accuracy using DII method. The seagrass area in Karang Bongkok Island is 19.5112 ha and in Kotok Island 2.5704 ha.

\section{References}

Agustin, R. 2014. Kontribusi Lamun dalam Regulasi Karbon dan Stabilisasi Ekosistem. Disertasi. Bogor Agricultural University. Bogor. 116 pp.

Amran MA. 2010. Estimation of Seagrass Coverage by Depth Invariant Indices on Quickbird Imagery. Biotropia. 17(1) : 42-50

Bortone, S.A, 2000. Seagrass: Monitoring, ecology. physiology and management. CRC press.

Budhiman, S., Winarso, G., \& Asriningrum, W. 2013. Pengaruh Pengambilan Training Sample Substrat Dasar Berbeda pada Koreksi Kolom Air Menggunakan Data Penginderaan Jauh. J. Penginderaan Jauh. (2): 83-91

Candade, N. \& Dixon, B. 2004. Multispectral Classification of Landsat Images: A Comparison of Support Vector Machine and Neural Network Classifiers. In: Hoffer R, Lane BE, editor. ASPRS Annual Conference Proceedings, Denver, Colorado. P. doi: 10.1.1.456.2338_2

Congalton, R. G. \& Green, K. 2009. Assesing the Accuracy of Remotely Sensed Data. Principles and Practices. 2th Edition. New York: CRC Press Taylor and Francis Group. doi: 10.1016/j.jag. 2009.07.002

Costanza, R., D’Arge, R., De Groot, R., Farber, S., Grasso, M., Hannon, B., Limburg, K., Naeem, S., O'Neill, R.V., Paruelo,J., Graskin,R.G., Sutton, P., \& Belt, M. 1997. The Value of the World's Ecosystem Service and Natural Capital. Nature. 387:253-260.

English S, Wilkinson C \& Baker V. 1997. Survey Manual for Tropical Marine Resources. Australia: Mc Graw Publication.

Green, E. P, Mumby, P.J., Edwards, A.J. \& Clark C.D. 2000. Remote sensing handbook for tropical coastal management. Paris: UNESCO. ISBN 923-103736-6

Grodecki, J. \& Dial, G. 2003. Block adjustment of high-resolution satellite images described by Rational Polynomials. Photogramm Eng. Remote Sens. 69(1):59-68. doi: 10.14358/PE RS.69.1.59

Lyzenga, D.R., 1981. Passive Remote-Sensing Techniques for Mapping Water Depth and Bottom Features. Applied Optics. 17:379-383. doi: 10.1364/AO.17.000379

McKenzie, Campbell S.J. \& Roder C.A. 2003. Seagrasswatch: Manual for mapping \& monitring seagrass resources by community (citizen) volunteers $2 \mathrm{sd}$ edition. The state of Queensland, Department of Primary Industries, CRC Reef. Queensland. pp 104. ISBN:09579741

Mehta, A., Ribeiro, E., Gilner, J. \& Woesik, R.V. 2007. Coral Reef Texture Classification Using Support Vector Machine. In: Braz J, Ranchordas A, Araújo HJ, Madeiras Pereira J, editor. International Conference VISIGRAPP 2007, Barcelona (SP), Spriger. P

Mountrakis, G., Lm, J. \& Ogole, C. 2011. Support vector machines in remote sensing: A review. ISPRS J. Photogramm. 66(3):247-259. doi: 10. 1016/j.isprsjprs.2010.11.001

Ritcher. 2004. ATCOR: Atmospheric and Topographic Correction. DLR. Remote Sensing Data Center. German: German Aerospace Center. 
Roelfsema C.M., Phin S.R., Udy N. \& Maxwell P., 2009. An Interrated Field and Remote Sensing Approach for Mapping Seagrass Cover, Morenton Bay, Australia. Spatial Science. 54 (1): 45-62. doi: 10.1080/14498596.2009.963 5166

Ryan, R., Baldridge, B., Schowengerdt, R.A., Choi, T., Hekder, D.L. \& Blonski, S., 2003. IKONOS spatial resolution and image interpretability characterization. JRSE 88:37-52. doi: 10.1016 /j.rse.2003.07.006

Setiawan, F., Harahap, S.A., Adriani, Y. \& Hutahaean A.A.. 2012. Deteksi Perubahan Padang Lamun Menggunakan Teknologi Penginderaan Jauh Dan Kaitanya Dengan Kemampuan Menyimpan Karbon Di Perairan Teluk Banten .Jurnal Perikanan dan kelautan. ISSN:2088-3137

Supriatna, W. \& Sukartono. 2002. Teknik Perbaikan Data Digital (Koreksi dan Penajaman) Citra Satelit. Bul. Teknik Pertanian. 7(1):4-6
Tamondong, A.M., Blanco, A.C. \& Fortes, M.D., Nadaoka K. 2013. Mapping of Seagrass and Other Bentic Habitat in Balinao, Pangasinan Using WorldView-2 Satellite Image. IGARSS. 1579-1582

United States Geological Survey (USGS). 2015. Landsat 8 satelitte images. Available at: http://landsat.usgs.gov/landsat8.php Accessed 12 April 2016

Vapnik., V., 1995. The Nature of Statistical Learning Theory. NY: Springer-Verlag. doi: 10.1007/9781-4757-3264-1

Vapnik, V.N. \& Kotz, S. 1982. Estimation of dependences based on empirical data. Springer-Verlag New York. doi: 10.1007/0-38734239-7

Wahiddin, N. 2015. Klasifikasi Ekosistem Terumbu Karang Berbasis Objek dan Piksel di PULAU Morotai Disertasi. Bogor Agricultural University. Bogor. 102 pp. 